\title{
Pengembangan Pendederan Ikan Kerapu melalui Peningkatan Kapasitas Kelompok untuk Penguatan Komoditas Unggulan Kabupaten Administratif Kepulauan Seribu, Jakarta
}

\section{(Grouper Nursery Development through Group Capacity Building for Leading Commodity Strengthen of Seribu Islands Administrative District, Jakarta)}

\author{
Irzal Effendi ${ }^{12^{*}}$, Iis Diatin ${ }^{1}$, Tatag Budiardi ${ }^{1}$, Yani Haderoseyani ${ }^{1}$ \\ ${ }^{1}$ Departemen Budidaya Perairan, Fakultas Perikanan dan Ilmu Kelautan, Institut Pertanian Bogor, \\ Kampus IPB Dramaga, Bogor 16680. \\ 2 Pusat Kajian Sumberdaya Pesisir dan Lautan, Lembaga Penelitian dan Pengabdian kepada Masyarakat, \\ Institut Pertanian Bogor, Kampus IPB Baranangsiang, Bogor 16144. \\ *Penulis Korespondensi: irzalef@apps.ipb.ac.id \\ Diterima November 2020/Disetujui Mei 2021
}

\begin{abstract}
ABSTRAK
Pendederan perlu dikembangkan untuk menguatkan ikan kerapu sebagai komoditas unggulan Kabupaten Administratif Kepulauan Seribu, Jakarta. Pengembangan usaha pendederan ini dilakukan melalui pengembangan sumber daya manusia (SDM) dan teknologi tepat guna (TTG). Pendederan ikan kerapu diharapkan bisa menjadi unit usaha baru di kabupaten yang sebagian besar kawasannya berupa laut. Kegiatan ini bertujuan untuk mengembangkan SDM dan TTG pendederan ikan kerapu melalui pelatihan, percontohan, dan pendampingan. Kegiatan dilakukan kepada 23 orang anggota masyarakat yang tergabung ke dalam tiga Pokdakan. Materi pelatihan mencakup aspek teknis dan manajemen usaha pendederan ikan kerapu. Percontohan dan pendampingan pendederan ini dilakukan secara paralel dengan pengembangan TTG aplikasi tepung meniran-bawang putih, dan dilakukan di Balai Sea Farming PKSPL-IPB, Kepulauan Seribu. Percontohan mencakup penyiapan karamba, penebaran benih, pemberian pakan, pengelelolaan kualitas air dan kesehatan ikan, sampling, pemanenan dan penanganan pascapanen. Pendampingan dilakukan dengan melayani kunjungan peserta ke balai, wawancara, dan pertemuan. Setelah pelatihan terjadi peningkatan pengetahuan dan keterampilan serta munculnya motivasi untuk melakukan pendederan ikan kerapu. Pada saat percontohan dan pendampingan keterlibatan dan antusias peserta relatif tinggi dengan berbagai aspek yang didiskusikan. Aplikasi tepung meniran-bawang putih dalam pakan pada pendederan ikan kerapu dapat memperbaiki rasio konversi pakan, sehingga biaya pakan menjadi lebih hemat. Salah satu peserta telah mencoba melakukan usaha pendederan ikan kerapu bebek secara mandiri, dan diperoleh keuntungan setelah dua bulan pemeliharaan.
\end{abstract}

Kata kunci: kerapu, pelatihan, pendampingan, pendederan, percontohan.

\begin{abstract}
Nursery needs to be developed to strengthen the grouper as a superior commodity for the Seribu Islands Administrative District, Jakarta. This effort is carried out through the development of human resources (HR) and appropriate technology (AT), and hoped that the grouper nursery will become a new business unit in this district, where most of the area is sea. This activity aims to develop HR and AT for grouper nursery through training, piloting, and mentoring. This activity was carried out to 23 community members who are members of the three fish farmer groups. The training materials including the technical and management aspects of the grouper nursery. The piloting and mentoring of grouper nursery were carried out in parallel with the development of AT in the form of the application of garlic-meniran flour, and were carried out at the Sea Farming Center of PKSPL-IPB, Seribu Islands. The piloting includes preparing of cages, stocking of seeds, feeding, water quality and fish health management, sampling, harvesting, and post-harvest handling. The mentoring is carried out by serving participant visits to the center, interviews and meetings. After the training there was an increase in knowledge and skills of the participants, as well as the emergence of motivation to start a grouper nursery business. During the piloting and mentoring, the involvement and enthusiasm of the participants was relatively high and various aspects were discussed. The application of meniran-garlic flour in feeding on grouper nurseries can improve the feed conversion ratio, so that feed costs are more efficient. One of the participants has tried to run humpback grouper fish farming independently, and made a profit after two months of rearing.
\end{abstract}

Key words: groupers, mentoring, nursery, piloting, training 


\section{PENDAHULUAN}

Kabupaten Administratif Kepulauan Seribu merupakan salah satu wilayah DKI Jakarta yang terletak di bagian utara dan sebagian besar $\left(6.997,00 \mathrm{~km}^{2}\right.$ atau $\left.99,87 \%\right)$ berupa lautan, dan sebagian kecil saja $\left(8,76 \mathrm{~km}^{2}\right.$ atau $\left.0,13 \%\right)$ berupa daratan, dengan 110 pulau yang 11 pulau di antaranya merupakan kawasan pemukiman. Kabupaten ini menjadi pemasok utama ikan kerapu DKI Jakarta dan/atau kawasan megapolitan Jabodetabek (Jakarta, Bogor, Depok, Tangerang, dan Bekasi). Ikan kerapu menjadi komoditas unggulan kabupaten ini yang diproduksi oleh masyarakat melalui pembesaran dalam keramba jaring apung (KJA) di laut (Soebagio 2005, Sari et al. 2008, Sari \& Nababan 2009). Ikan kerapu diproduksi oleh sekitar 23 kelompok pembudidaya ikan (Pokdakan) binaan pemerintah daerah yang berdomisili di tiga kelurahan, yaitu Kelurahan Pulau Panggang (12 Pokdakan), Pulau Tidung (9 Pokdakan), dan Pulau Kelapa (2 Pokdakan) (BPS 2020). Ikan kerapu dari pembudidaya dijual ke pengumpul (offtaker) lokal yang kemudian ke pengumpul besar di DKI Jakarta, selanjutnya ke retailer, restoran seafood, dan hotel di kawasan pemasaran tersebut. Spesies yang diproduksi umumnya adalah ikan kerapu macan (Epinephelus fuscoguttatus), ikan kerapu cantang (Epinephelus sp.), ikan kerapu cantik (Epinephelus sp.), dan ikan kerapu bebek (Cromileptes altivelis). Indonesia merupakan eksportir ikan kerapu yang sebagian besar ( $>90 \%$ ) ke Hongkong yang pada Januari 2020 mencapai 165,87 ton, (Suhana 2020). Permintaan sea food di Indonesia cenderung meningkat, meskipun sempat mengalami penurunan akibat pandemi Covid-19, namun permintaan ikan kerapu kembali meningkat mulai pertengahan 2020 (Trana et al. 2017, Love et al. 2021).

Permasalahan utama dalam usaha pembesaran ikan kerapu di Kepulaun Seribu adalah ketersediaan benih yang tepat waktu, tepat mutu, tepat jumlah, dan tepat harga (4T). Benih ikan kerapu ukuran 5-9 cm didatangkan dari luar wilayah, yakni dari panti pembenihan (hatchery) di Jawa Timur, Bali, dan Lampung dengan moda angkutan udara, darat, dan laut hingga ke tiga lokasi pembesaran di tiga kelurahan tersebut. Pembudidaya memerlukan waktu sekitar satu tahun untuk membesarkan benih ikan kerapu tersebut hingga mencapai ukuran konsumsi (marketable size), yakni sekitar $0,5 \mathrm{~kg} /$ ekor dengan tingkat kelangsungan hidup berkisar antara 50-90\% (Effendi 2019). Untuk meningkatkan peluang keberhasilan panen pembesaran ikan kerapu dengan tingkat kelangsungan hidup yang lebih tinggi dan lama pemeliharaan yang lebih singkat maka perlu dikembangkan usaha pendederan. Pengembangan usaha pendederan juga diharapkan bisa menciptakan usaha baru dan lapangan pekerjaan, meningkatkan perekonomian wilayah, mempersingkat lama pemeliharaan, dan memperbanyak siklus produksi. Pendederan adalah segmentasi usaha dalam akuakultur, yakni membesarkan benih dari panti pembenihan hingga mencapai ukuran yang lebih besar dan lebih kuat untuk usaha pembesaran (Effendi 2010).

Pengembangkan pendederan ikan kerapu sebagai segmentasi usaha baru, perlu penyiapan dan pengembangan pembudidaya yang terhimpun dalam Pokdakan, yakni melalui kegiatan pelatihan, percontohan, dan pendampingan. Mengacu kepada Dickson et al. (2016), pelatihan berbasis lapangan dengan materi berupa cara atau praktik pengelolaan budi daya ikan yang baik (best management practices) bisa meningkatkan profitabilitas usaha, terutama pada usaha budi daya yang baru dikembangkan. Pelatihan dan percontohan farming (demfarm) dengan pendekatan kelompok bisa memberi hasil yang lebih baik (Srinath et al. 2000). Beberapa faktor yang memengaruhi pembudidaya dalam mengadopsi teknologi antara lain pendidikan, diversifikasi kegiatan on-farm, ukuran wadah budi daya, tingkat produksi, kehadiran dalam pelatihan penyuluhan, kemudahan pemahaman, dan kemudahan teknologi penanganan (Obiero et al. 2019). Kegiatan ini bertujuan untuk memberikan wawasan, keterampilan, dan motivasi serta mengembangkan teknologi tepat guna dan menciptakan segmentasi usaha baru, yakni usaha pendederan ikan kerapu bagi Kelompok Seafarming di Pulau Pramuka dan Panggang, Kelurahan Pulau Panggang, Kepulauan Seribu dalam rangka menguatkan agrbisnis ikan kerapu sebagai komoditas unggulan daerah. Selain itu, untuk mengembangkan SDM dan TTG pendederan ikan kerapu dalam KJA di laut melalui pelatihan, percontohan, dan pendampingan.

\section{METODE PELAKSANAAN KEGIATAN}

\section{Lokasi dan Peserta}

Kegiatan pengabdian pada masyarakat dengan tema Pengembangan Pendederan Ikan 
Kerapu melalui Peningkatan Kapasitas Kelompok untuk Penguatan Komoditas Unggulan Kepulauan Seribu Jakarta ini berlangsung pada Agustus-Desember 2019. Kegiatan berlangsung di Kelurahan Pulau Panggang, Kecamatan Kepulauan Seribu Utara, Kabupaten Administratif Kepualauan Seribu yang merupakan salah satu wilayah DKI Jakarta yang terletak di bagian utara. Kelurahan ini memiliki dua pulau yang merupakan kawasan pemukiman yaitu Pulau Panggang dan Pulau Pramuka, pulau terakhir bahkan dijadikan sebagai pusat pemerintahan kabupaten. Di kelurahan ini terdapat 12 Pokdakan binaan pemerintah daerah, salah satunya adalah Sea Farming Pulau Panggang yang telah memiliki Anggaran Dasar dan Anggaran Rumah Tangga (Ikhsani 2011). Peserta kegiatan pengabdian pada masyarakat ini sebanyak 23 peserta yang berasal atau perwakilan dari tiga Pokdakan, yaitu Seafarming Pulau Panggang, Unit Pengembangan Budidaya Laut (UPBL), dan Nelayan Kerapu Pulau Seribu (NKPS) dengan ketua kelompok masing-masing adalah Nawawi, Rusli, dan Taufik.

\section{Konsep Kegiatan}

Kegiatan pengabdian pada masyarakat ini terdiri dari dari dua kegiatan utama, yaitu pengembangan SDM pembudidaya yang terhimpun dalam Pokdakan dan pengembangan TTG pendederan ikan kerapu (Gambar 1). Pengembangan SDM mencakup kegiatan pelatihan, percontohan dan pendampingan teknis dan manajemen usaha pendederan ikan kerapu.
Percontohan usaha (demontrasi farming atau demfarm) dilakukan setelah pelatihan dan dijadikan sebagai wahana penelitian untuk pengembangan TTG sebagai riset terapan atau riset aksi. Dengan demikian kedua kegiatan utama tersebut (pengembangan SDM dan TTG) dilakukan secara paralel dan diharapkan bisa menghasilkan TTG dan manajemen usaha pendederan serta penguasaannya oleh pembudidaya yang terhimpun dalam Pokdakan.

\section{Pelatihan}

Pelatihan dilakukan di balai warga Pulau Pramuka, Kelurahan Pulau Panggang, Kecamatan Kepulauan Seribu Utara selama tiga hari, dua hari di kelas dan hari terakhir di lapangan. Peserta pelatihan dibatasi sebanyak 23 orang pembudidaya yang merupakan perwakilan dari tiga Pokdakan, yaitu Sea Farming, UPBL, dan NKPS, serta berdomisili di Pulau Panggang dan Pramuka. Peserta pelatihan tersebut dipilih oleh ketua kelompok masing-masing dan diajukan melalui pengesahan oleh Lurah Kelurahan Pulau Panggang. Persyaratan peserta pelatihan adalah pembudidaya yang aktif, anggota Pokdakan, sehat, dan bersedia mengikuti pelatihan dari awal hingga akhir.

Materi pelatihan yang diberikan mencakup aspek teknis dan manajemen usaha pendederan ikan kerapu, yaitu: 1) Sistem produksi dan manajemen; 2) Pengelolaan benih; 3) Pengelolaan kualitas air; 4) Pengelolaan pemberian pakan; 5) Pengelolaan kesehatan ikan melalui aplikasi pengobatan herbal (fitofarmaka); dan 6) Analisis

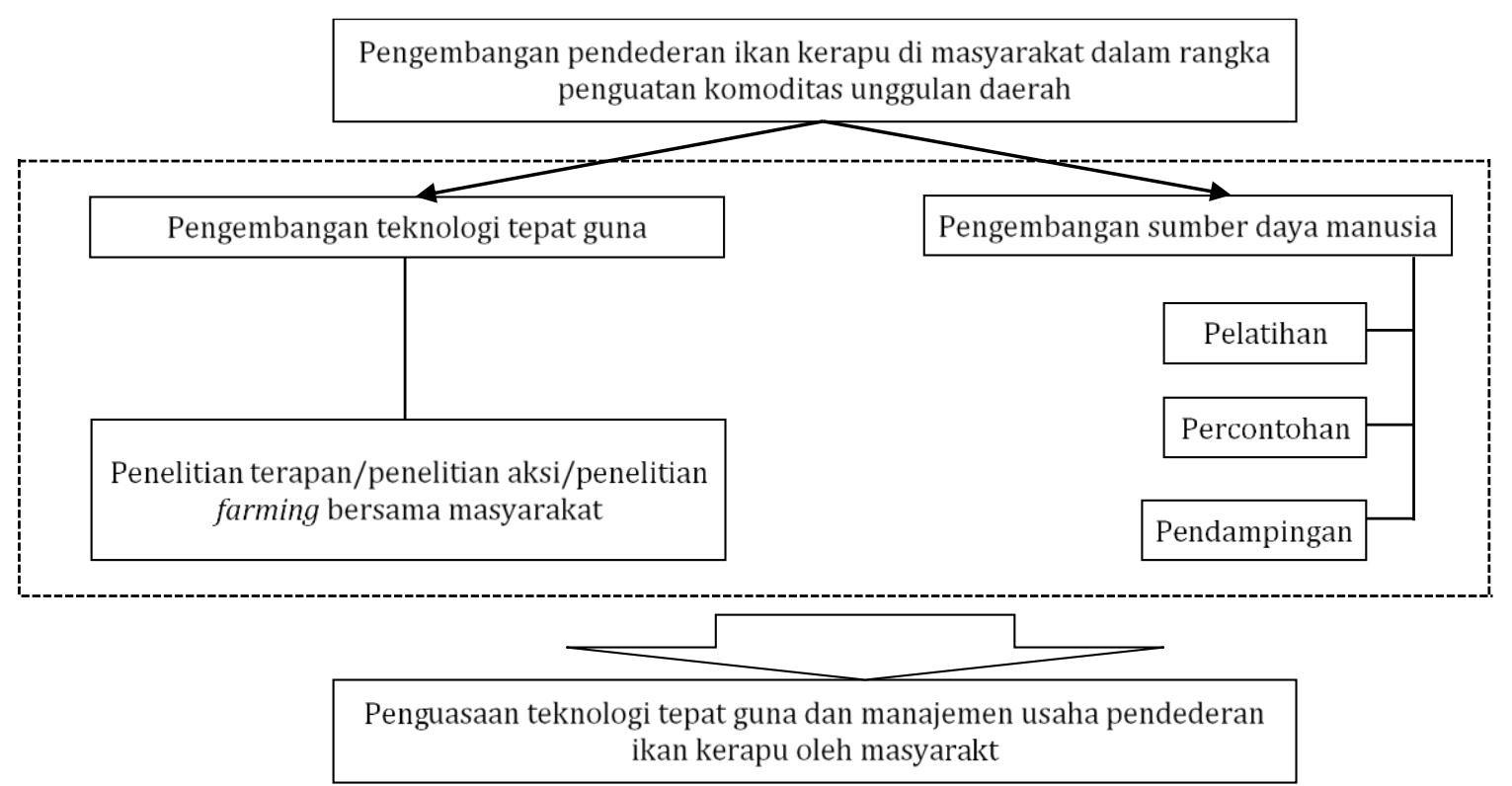

Gambar 1 Konsep pengembangan pendederan ikan kerapu di masyarakat untuk penguatan komoditas unggulan Kabupaten Administrasi Kepulauan Seribu. 
usaha dan enterpreneurship. Materi sistem produksi dan manajemen pendederan menggambarkan konsep pendederan yang akan dikembangkan dalam kerangka penguatan ikan kerapu sebagai komoditas unggulan daerah Kepulauan Seribu (Gambar 2). Pendederan yang akan dikembangkan adalah berbasis laut dengan menggunakan KJA dan benih pembenihan (hatchery) ukuran 3-5 cm (Effendi 2019). Ini adalah inovasi karena biaya pengangkutan ke laut untuk benih ukuran 3-5 cm menjadi lebih murah dibandikan dengan benih ukuran $9-11 \mathrm{~cm}$ yang didederkan di darat. Selama ini pendederan ikan kerapu umumnya dilakukan di darat hingga ukuran 9-11 cm, kemudian dibawa ke laut (Ismi 2010; Akbar et al. 2012). Pendederan ikan kerapu dalam KJA di laut pada kegiatan ini diharapkan diperoleh benih ukuran 9-11 atau 13-15 cm.

Materi terakhir mencakup kemampuan mencatat, pembukuan selain kemampuan mengambil keputusan dalam menjalankan usaha pendederan ikan kerapu. Setiap materi disampaikan selama 1,5 jam, sehingga untuk keseluruhan materi diperlukan waktu 12 jam atau enam jam per hari. Instruktur pelatihan adalah dosen IPB yang kompeten dengan materi pelatihan, dan dibantu oleh beberapa mahasiswa. Pelatihan dilakukan melalui ceramah, diskusi, dan peragaan (demonstrasi cara) di kelas, dan kunjungan lapangan (Dickson et al. 2016). Kunjungan lapangan dilakukan ke Balai Sea Farming Pusat Kajian Sumberdaya Pesisir dan Lautan (PKSPL) LPPM-IPB, perairan Pulau Semak Daun sebagai calon lokasi percontohan (Davis-Hodgkins 1999). Sebelum dan setelah pelatihan dilakukan tes atau ujian (pre-test dan post-test) untuk mengevaluasi kebehasilan pelatihan terkait pengetahuan, wawasan, dan keterampilan peserta (ITECH 2010). Pertanyaan yang diajukan pre-test dan post-test adalah sama dan disusun berdasarkan kepada materi yang diberikan dalam pelatihan tersebut, sehingga pengetahuan peserta sebagai dampak dari pelatihan dapat dievaluasi. Pada post-test ditambahkan pertanyaan terkait dengan minat mereka terhadap usaha pendederan setelah mendapatkan pelatihan, dan kendala yang dihadapi ketika bermaksud memulai usaha.

\section{Percontohan}

Percontohan usaha pendederan atau demfarm ikan kerapu diberikan kepada peserta kegiatan ini berprinsip kepada seing is believing, sehingga mempermudah proses disemininasi teknologi dan manajemen usaha (Voeten \& Ottens 1997). Percontohan dilakukan di perairan Pulau Semak Daun, Kelurahan Pulau Panggang, yakni pada KJA Balai Sea Farming PKSPL LPPM-IPB dan unit produksi milik masyarakat yang menjadi salah satu peserta kegiatan. Percontohan di Balai Sea Farming berupa pengembangan pendederan ikan kerapu cantang (Epinephelus sp.) dengan aplikasi bahan herbal tepung meniran (Phyllanthus niruri) dan bawang putih (Allium sativum), sedangkan di unit produksi masyarakat berupa pendederan ikan kerapu bebek (Cromileptes altivelis).

Kegiatan percontohan ini mencakup pengadaan input produksi (benih, pakan, dan obatobatan), penyiapan keramba, penebaran benih, pemberian pakan, pengelelolaan kualitas air dan kesehatan ikan, sampling, pemanenan, dan penanganan pascapanen hingga pengelolaan usaha, dan kelembagaan. Percontohan pendederan di KJA Balai Sea Farming dilakukan dalam skema penelitian terapan atau penelitian aksi untuk menghasilkan TTG berupa aplikasi bahan herbal untuk meningkatkan kesehatan dalam pendederan ikan kerapu cantang (Epinephelus sp.).

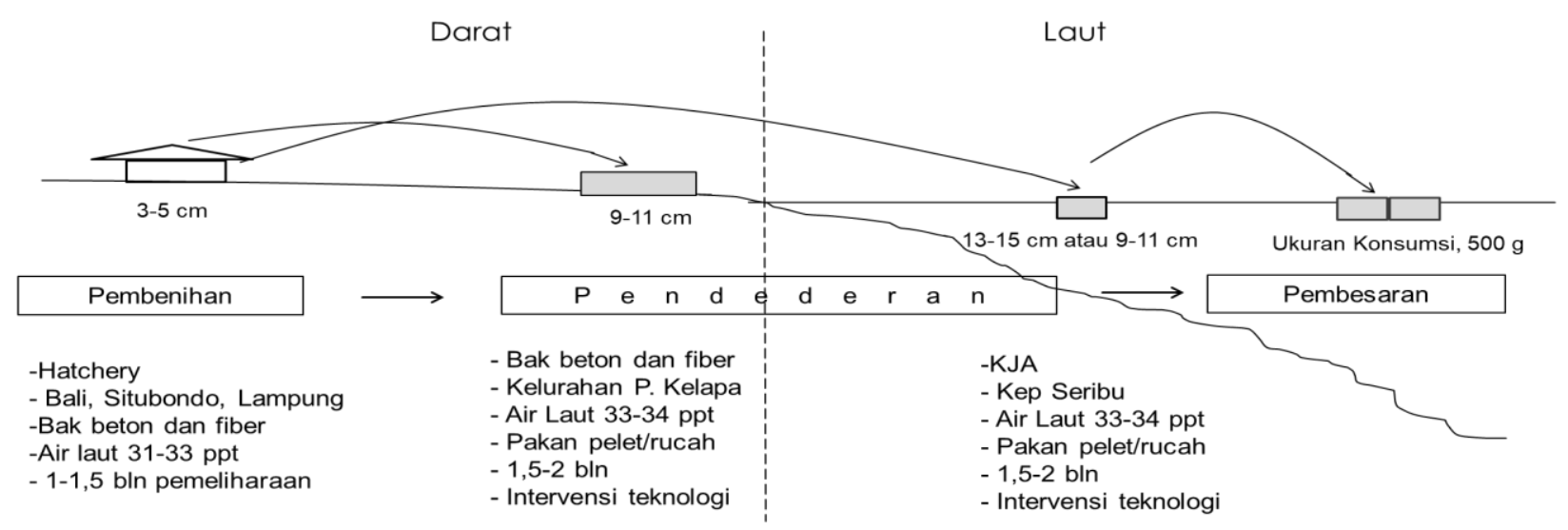

Gambar 2 Sistem produksi pendederan ikan kerapu dalam keramba jaring apung di laut yang akan dikembangkan (Effendi 2019). 
Penelitian terapan ini dilakukan selama 28 hari oleh satu orang mahasiswa IPB untuk penyusunan skripsi dalam rangka penyelesaian studi. Percontohan pendederan di KJA milik salah satu peserta kegiatan ini dilakukan selama 60 hari hingga diperoleh benih ikan kerapu bebek (Cromileptes altivelis) ukuran 9-11 cm.

Sebagai sebuah percontohan maka pada kedua unit pendederan tersebut dibuka kesempatan sebanyak mungkin kepada peserta kegiatan untuk berkunjung. Kehadiran, pertanyaan, dan ungkapan peserta selama percontohan tersebut berlangsung dicatat dan dikelompokkan. Beberapa pertanyaan dari peserta kegiatan bisa langsung di jawab oleh mahasiswa yang mengawal pendederan di Balai Sea Farming atau pelaksana percontohan di masyarakat, pertanyaan lainnya disampaikan ke dosen karena perlu jawaban yang lebih mendalam. Proses tersebut menjadikan unit percontohan ini berperan pula sebagai unit pendampingan.

\section{Pendampingan}

Pendampingan dilakukan bersamaan dengan percontohan pendederan ikan kerapu yang sedang berlangsung. Pendampingan atau mentoring ini dilakukan secara informal melalui kunjungan (anjangsana), pertemuan, dan diskusi tidak terjadwal di loksi percontohan (Rouhani \& Britz 2016). Balai Sea Farming, yang menjadi lokasi percontohan, merupakan tempat pertemuan informal atau formal baik antara dosen dan mahasiswa IPB serta teknisinya dengan pembudidaya atau Pokdakan maupun antar pelaku budi daya ikan kerapu di kawasan tersebut, terutama anggota Kelompok Sea Farming Pulau Panggang. Lokasi balai relatif berdekatan dengan lokasi KJA para peserta, yakni di kawasan perairan Pulau Semak Daun. Kondisi di atas tentunya memudahkan untuk terjadinya trasfer pengetahuan, wawasan, dan keterampilan usaha pendederan ikan kerapu kepada para peserta kegiatan ini dan masyarakat pembudidaya ikan kerapu pada umumnya.

Pendampingan juga berlangsung di unit percontohan milik masyarakat, yakni Ketua Kelompok Sea Farming Pulang Panggang. Dengan kedudukannya sebagai ketua kelompok yang musti melayani anggota, maka unit percontohannya menjadi wahana pendampingan bagi seluruh peserta kegiatan juga. Pendampingan diberikan kepada ketua kelompok yang langsung memulai usaha pendederan secara mandiri ini, antara lain membantu pengadaan benih dan pakan ikan kerapu bebek dan memberikan saran teknis berupa kunjungan dan konsulltasi, serta membantu cara pencatatan teknis dan biaya.

\section{Pengembangan Teknologi Tepat Guna}

Pengembangan TTG berupa penelitian terapan pendederan ikan kerapu dalam KJA di Balai Sea Farming, dan dilakukan oleh mahasiswa untuk penyusunan skripsi di bawah bimbingan dosen IPB. Penelitian terapan ini berupa penelitian aksi untuk membantu memecahkan masalah kesehatan dan serangan wabah penyakit yang biasa menyerang ikan kerapu dalam wadah budi daya. TTG yang dikembangkan adalah aplikasi pengobatan herbal tepung meniran dan bawang putih pada pendederan ikan kerapu dalam KJA di laut yang mengacu kepada Wahyuningrum et al. 2013; Wahyuningrum et al. 2016.

Kegiatan ini mencakup penyusunan rancangan penelitian, penyiapan wadah, pengadaan dan penebaran benih ikan, penyiapan tepung meniran dan bawang putih, pengadaan dan pemberian pakan bahan, pengelolaan kualitas air, sampling, pengumpulan data, dan pemanenan. Pengumpulan data ditujukan untuk mengetahui kinerja produksi pendederan ikan kerapu yang diberi perlakuan obat herbal tersebut. Kinerja produksi yang diukur mencakup kelangsungan hidup, pertumbuhan, dan rasio konversi pakan (feed conversion ratio, FCR). Dari penelitian ini diharapkan dihasilkan TTG pengobatan herbal pada ikan dalam rangka meningkatkan keberhasilan dan produktivitas pendederan ikan kerapu.

\section{Analisis Usaha}

Analisis usaha dilakukan pada pendederan ikan kerapu bebek yang dilakukan oleh peserta, yakni dengan menghitung keuntungan usaha secara sederhana. Untuk itu biaya yang dikeluarkan (total cost, TC), baik biaya tetap maupun biaya variabel, serta penerimaan (R) yang akan diterima dari penjualan benih hasil dederan dan dicatat dan dihitung untuk menentukan keuntungan usaha $(\pi)$, dengan menggunakan formula $\pi=\mathrm{R}-\mathrm{TC}$.

\section{HASIL DAN PEMBAHASAN}

\section{Pelatihan}

Pelatihan dalam rangka pengembangan pendederan ikan kerapu di masyarakat untuk penguatan komoditas unggulan Kabupaten 
Administratif Kepulauan Seribu ini telah diikuti oleh 23 orang peserta (Gambar 3). Peserta berasal dari tiga Pokdakan ikan kerapu yang berdomisili di Pulau Panggang dan Pulau Pramuka, yaitu Kelompok Sea Farming Pulau Panggang, Kelompok UPBL, dan NKPS. Pelatihan berlangsung selama 3 hari yang mencakup orientasi lapangan berupa kunjungan ke Balai Sea Farming perairan Pulau Semak Daun
Kepulauan Seribu (hari I), penyampaian materi berupa ceramah, diskusi, dan demonstrasi cara (hari II), dan evaluasi pelatihan (hari III) (Tabel 1). Materi pelatihan yang diberikan sesuai dengan rencana yang telah disusun, namun urutannya mengalami perubahan. Pada hari II dan III pelatihan dilakukan masing-masing pretest dan post-test untuk menguji keberhasilan pelatihan. Berdasarkan hasil pre-test dan post-

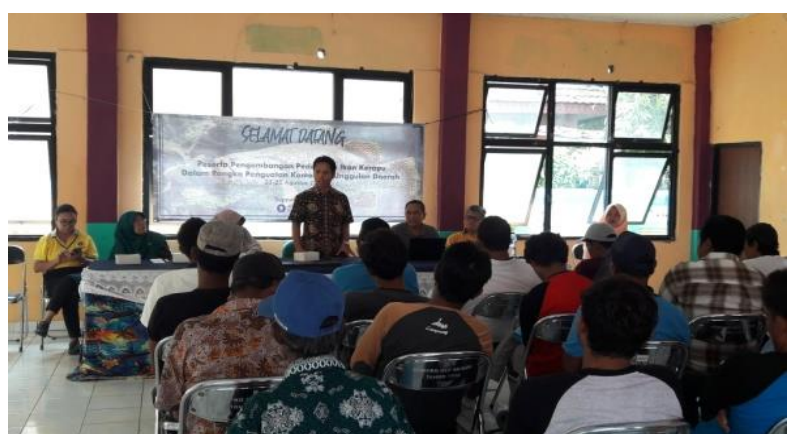

a

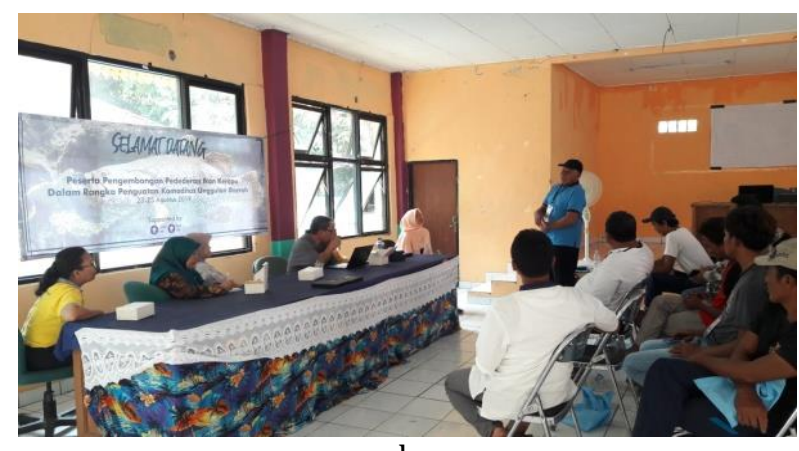

b

Gambar 3 Suasana pelatihan pengembangan pendederan ikan kerapu di masyarakat dalam rangka penguatan komoditas unggulan Kabupaten Administratif Kepulauan Seribu: a) sambutan Bapak Lurah Kelurahan Pulau Panggang, b) Harapan dari peserta yang disampaikan oleh Ketua Kelompok Sea Farming Pulau Panggang.

Tabel 1 Agenda pelatihan pengembangan pendederan ikan kerapu di masyarakat dalam rangka penguatan komoditas unggulan Kabupaten Administratif Kepulauan Seribu

\begin{tabular}{|c|c|c|c|c|}
\hline Hari/tanggal & Waktu & Materi/kegiatan & $\begin{array}{l}\text { Pemateri/penanggung } \\
\text { jawab }\end{array}$ & Tempat \\
\hline \multirow[t]{6}{*}{$\begin{array}{l}\text { Jumat/23 } \\
\text { Agustus } 2019\end{array}$} & $14.00-17.00$ & $\begin{array}{lrr}\text { Orientasi } & \text { lapangan dan } \\
\text { persiapan } & \text { percontohan } \\
\text { pendederan ikan kerapu }\end{array}$ & Irzal Effendi & $\begin{array}{l}\text { Balai Sea Farming dan } \\
\text { perairan Pulau Semak } \\
\text { Daun }\end{array}$ \\
\hline & $09.00-09.25$ & Regristrasi peserta pelatihan & Panitia & $\begin{array}{l}\text { Balai Warga Kelurahan } \\
\text { Pulau Pramuka }\end{array}$ \\
\hline & $09.25-09.35$ & Pembukaan & Irzal Effendi & $\begin{array}{l}\text { Balai Warga Kelurahan } \\
\text { Pulau Pramuka }\end{array}$ \\
\hline & $09.35-09.45$ & $\begin{array}{l}\text { Kata sambutan Dep. BDP FPIK- } \\
\text { IPB }\end{array}$ & Tatag Budiardi & $\begin{array}{l}\text { Balai Warga Kelurahan } \\
\text { Pulau Pramuka }\end{array}$ \\
\hline & $09.45-09.55$ & $\begin{array}{lr}\text { Kata sambutan } & \text { Lurah Pulau } \\
\text { Panggang } & \text { Kecamatan }\end{array}$ & Pepen Kuswandi & $\begin{array}{l}\text { Balai Warga Kelurahan, } \\
\text { Pulau Pramuka }\end{array}$ \\
\hline & $09.55-10.10$ & $\begin{array}{l}\text { Kepulauan Seribu Utara } \\
\text { Sambutan dan harapan peserta } \\
\text { pelatihan }\end{array}$ & Rusli & $\begin{array}{l}\text { Balai Warga Kelurahan } \\
\text { Pulau Pramuka }\end{array}$ \\
\hline \multirow[t]{7}{*}{$\begin{array}{l}\text { Sabtu/24 } \\
\text { Agustus } 2019\end{array}$} & $10.10-10.15$ & Pembacaan doa & Andi & $\begin{array}{l}\text { Balai Warga Kelurahan } \\
\text { Pulau Pramuka }\end{array}$ \\
\hline & $10.15-11.00$ & $\begin{array}{l}\text { Sistem produksi pendederan } \\
\text { ikan kerapu di laut }\end{array}$ & Irzal Effendi & $\begin{array}{l}\text { Balai Warga Kelurahan } \\
\text { Pulau Pramuka }\end{array}$ \\
\hline & $11.00-11.45$ & $\begin{array}{l}\text { Kualitas air dalam pendederan } \\
\text { ikan kerapu }\end{array}$ & Tatag Budiardi & $\begin{array}{l}\text { Balai Warga Kelurahan } \\
\text { Pulau Pramuka }\end{array}$ \\
\hline & $11.45-12.30$ & Benih ikan kerapu & Dinar Tri Soelistyowati & $\begin{array}{l}\text { Balai Warga Kelurahan } \\
\text { Pulau Pramuka }\end{array}$ \\
\hline & $12.30-14.00$ & ISOMA & Panitia & \\
\hline & $14.00-14.45$ & $\begin{array}{l}\text { Analisis usaha pendederan ikan } \\
\text { kerapu }\end{array}$ & Iis Diatin & $\begin{array}{l}\text { Balai Warga Kelurahan } \\
\text { Pulau Pramuka }\end{array}$ \\
\hline & $14.45-15.30$ & $\begin{array}{l}\text { Pengelolaan kesehatan ikan: } \\
\text { aplikasi obat-obatan herbal }\end{array}$ & Yani Hadiroseyani & $\begin{array}{l}\text { Balai Warga Kelurahan } \\
\text { Pulau Pramuka }\end{array}$ \\
\hline $\begin{array}{l}\text { Minggu/25 } \\
\text { Agustus } 2019\end{array}$ & $9.00-12.00$ & Evlauasi pelatihan & Yani Hadiroseyani & $\begin{array}{l}\text { Balai Warga Kelurahan } \\
\text { Pulau Pramuka }\end{array}$ \\
\hline
\end{tabular}


test terjadi peningkatan pengetahuan setelah diberikan pelatihan. Rata-rata peserta yang menjawab dengan tepat sebelum diberikan pelatihan adalah $40,43 \%$ dan setelah pelatihan naik menjadi $73,04 \%$, atau hampir dua kali (Tabel 2).

Umumnya peserta pelatihan merasa mampu memelihara ikan kerapu berukuran besar dalam sistem pembesaran, namun ketika dihadapkan kepada pemeliharaan ikan yang berukuran lebih kecil dalam sistem pendederan mereka merasa tidak percaya diri. Pelatihan yang biasa peserta terima selama ini adalah usaha budi daya pembesaran ikan kerapu dalam KJA dan keramba jaring tancap (KJT), dan pelatihan teknologi dan manajemen usaha pendederan ini baru pertama kali diperoleh. Terdapat perbedaan teknologi pendederan dengan pembesaran, yakni terkait dengan ukuran ikan yang dipelihara, daya tahan ikan menghadapi lingkungan laut, tingkah laku ikan, ukuran kantong KJA dan mata jaring (mesh size), padat penebaran, jenis ukuran dan waktu pemberian pakan, dan sebagainya. Pendederan ikan kerapu membutuhkan perhatian, ketelatenan, dan intensitas pekerjaan yang lebih tinggi dibandingkan dengan pembesaran.

Setelah pelatihan, minat peserta untuk melakukan usaha pendederan tampaknya tinggi (91,3\%), namun terkendala oleh modal kerja. Sebagaian besar peserta pelatihan berharap bisa melakukan sendiri usaha pendederan di bawah pendampingan oleh IPB. Peserta juga berharap percontohan dilakukan pada fasilitas produksinya dengan bantuan pendanaan dan pedampingan. Peserta pelatihan berharap pendampingan yang intensif pada saat mereka mencoba usaha pendederan hingga panen. Untuk memfasilitasi pembelajaran dan pemanfaatan teknologi dan praktik yang baik oleh para peserta, tampaknya berbagai materi penyuluhan dan komunikasi terkait pendederan ikan kerapu, termasuk poster, brosur informasi hard copy dalam bahasa yang sederhana, presentasi video singkat, dan fitur radio perlu diadakan sebagaimana yang dilakukan oleh Obiero et al. (2019).

\section{Percontohan dan Pendampingan}

Percontohan pendederan ikan kerapu berperan juga sebagai upaya pendampingan masyarakat. Percontohan telah dilakukan di KJA Balai Sea Farming PKSPL LPPM-IPB dan unit produksi milik masyarakat yang menjadi salah satu peserta kegiatan. Percontohan di Balai Sea Farming berupa pengembangan pendederan ikan kerapu cantang dengan aplikasi bahan herbal tepung meniran dan bawang putih, sedangkan unit produksi masyarakat berupa pendederan ikan kerapu bebek. Kegiatan percontohan ini mencakup pengadaan input produksi (benih, pakan, dan obat-obatan), penyiapan keramba, penebaran benih, pemberian pakan, pengelolaan kualitas air dan kesehatan ikan, sampling, pemanenan, dan penanganan pascapanen hingga pengelolaan usaha. Pelaksanaan percontohan ini melibatkan masyarakat, terutama saat pengangkutan benih, penebaran, pemberian pakan, penanganan ikan yang terserang penyakit dan pemanenan. Keterlibatan masyarakat ini diharapkan bisa memperbesar peluang keberhasilan kegiatan (Rouhani \& Britz 2011).

Peserta kegiatan dan masyarakat datang ke lokasi percontohan, baik di KJA Balai Sea Farming maupun miliki salah satu peserta, bisa mendapatkan informasi dan penjelasan tentang teknologi pendederan ikan kerapu. Pada percontohan di Balai Sea Farming, peserta mendapatkan pendampingan dari mahasiswa penelitian dan teknisi yang terlibat dalam percontohan, atau dari dosen yang melakukan supervisi. Mahasiswa dan teknisi tinggal di lokasi percontohan, sehingga bisa ditemui dengan mudah oleh masyarakat kapan saja. Ini adalah bentuk pendampingan sepanjang hari yang

Tabel 2 Jumlah peserta (orang) yang menjawab dengan benar pre-test dan post-test pada pelatihan pengembangan pendederan ikan kerapu di masyarakat dalam rangka penguatan komoditas unggulan Kabupaten Administratif Kepualauan Seribu berupa (angka dalam kurung dinyatakan dalam persen, yakni persentase jumlah peserta yang menjawab dengan benar terhadap jumlah keseluruhan peserta)

\begin{tabular}{cccccccccccc}
\hline \multirow{2}{*}{ Ujian } & 1 & 2 & 3 & 4 & 5 & 6 & 7 & 8 & 9 & 10 & Rata-rata \\
\cline { 2 - 11 } Pre-test & 12 & 11 & 14 & 10 & 12 & 9 & 8 & 6 & 6 & 5 & \\
& $(52,17)$ & $(47,83)$ & $(60,87)$ & $(43,48)$ & $(52,17)$ & $(39,13)$ & $(34,78)$ & $(26,09)$ & $(26,09)$ & $(21,74)$ & $(40,43)$ \\
Post-test & 15 & 16 & 20 & 15 & 18 & 19 & 17 & 15 & 16 & 17 & \\
& $(65,22)$ & $(69,57)$ & $(86,96)$ & $(65,22)$ & $(78,26)$ & $(82,61)$ & $(73,91)$ & $(65,22)$ & $(69,57)$ & $(73,91)$ & $(73,04)$ \\
\hline Jumlah peserta & 23 & 23 & 23 & 23 & 23 & 23 & 23 & 23 & 23 & 23 & \\
\hline
\end{tabular}


bersifat aksi langsung. Percontohan farming pendederan ini sekaligus sebagai pendampingan peserta yang datang ke lokasi. Peserta pelatihan terlibat langsung dalam percontohan pendederan ikan kerapu, sejak pemasangan kantong jaring pada KJA, pengangkutan benih ikan kerapu dari kapal ke lokasi percontohan, pemberian pakan harian, pengelolaan kualitas air berupa pengukuran kualitas air dan pembersihan dinding jaring dari sampah dan biota penempel (biofouling), sampling ikan untuk mengetahui panjang, bobot, pemanenan benih dan pengangkutan benih ke lokasi unit pembesaran (Gambar 4).

Minat peserta kegiatan ini sangat tinggi karena merupakan hal yang baru, yang sebelumnya mereka hanya melakukan pembudidayaan pembesaran saja. Selama masa percontohan pendederan, baik yang berlangsung di Balai Sea Farming PKSPL LPPM-IPB maupun unit produksi milik salah satu peserta, kehadiran harian peserta rata-rata 2 orang/hari. Kehadiran peserta pada kegiatan percontohan sangat tinggi pada saat tertentu, yaitu saat penebaran benih dan pemanenan. Kunjungan peserta ke lokasi percontohan ini umumnya bertujuan untuk mengetahui, memahami, dan menambah keterampilan pendederan ikan kerapu. Pertanyaan atau aspek yang diajukan atau didiskusikan oleh peserta pada saat kunjungan ke unit percontohan tersebut mencakup aspek benih ikan kerapu (kualitas, kuantitas, dan sumber benih), penyakit ikan (jenis dan cara penanganan), pakan ikan (jenis, jumlah, waktu, dan frekuensi pemberian pakan), biaya dan harga (benih, obat-obatan, dan pakan buatan), kualitas air (parameter penting dan cara pengukuran kualitas air), kelangsungan hidup benih (jumlah ikan yang sakit dan mati, penyebab kematian, tanda-tanda ikan yang mati), pertumbuhan benih (panjang dan bobot), ukuran panen (panjang dan bobot), waktu dan ukuran panen, dan harga benih (Tabel 3).

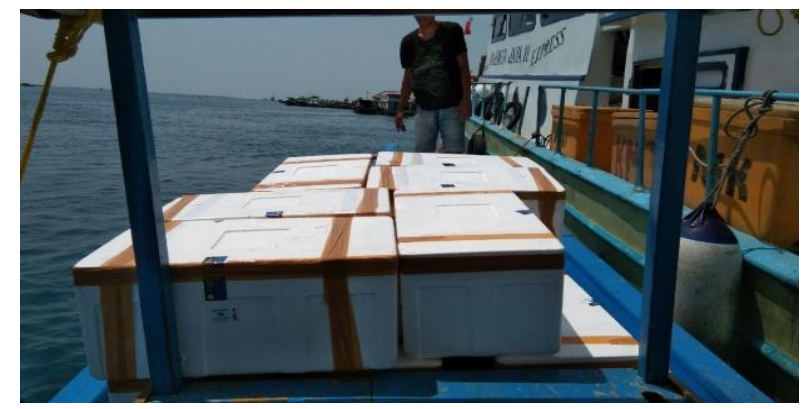

a

\section{Pengembangan TTG}

Pengembangan TTG pendederan ikan kerapu berupa aplikasi obat herbal tepung meniran dan bawang putih telah dilakukan melalui penelitian aksi yang dikemas sebagai bentuk percontohan. Benih ikan kerapu cantang yang berukuran 4-5 cm yang didatangkan dari backyard hatchery di Situbondo ini dipelihara dalam KJA berukuran 3 x 3 x $3 \mathrm{~m}$ sebanyak 5 unit dengan kepadatan 1.000 ekor/wadah atau $111 \mathrm{ekor} / \mathrm{m}^{2}$. Benih ikan kerapu diberi pakan buatan dengan kandungan protein $47 \%$ sekenyangnya dengan frekuensi setiap 2-3 jam. Aplikasi tepung meniran-bawang putih diterapkan pada benih ikan kerapu ketika mencapai ukuran $8 \mathrm{~cm}$, dengan mengacu kepada Wahyuningrum et al. 2013; Wahyuningrum et al. 2016.

Ekstrak tepung meniran dan bawang putih diperoleh dengan cara batang, daun, dan akar tanaman meniran dicuci kemudian dikeringkan dalam selama 18 jam pada $40^{\circ} \mathrm{C}$, kemudian dihaluskan hingga menjadi tepung menggunakan grinder (Wahyuningrum et al. 2013;

Tabel 3 Pertanyaan atau aspek yang diajukan oleh peserta pada saat percontohan dan pendampingan pengembangan pendederan ikan kerapu berlangsung di Balai Sea Farming PKSPL LPPM-IPB perairan Pulau Semak Daun Kepulauan Seribu

\begin{tabular}{lcr}
\hline \multicolumn{1}{c}{ Pertanyaan/aspek } & Jumlah & $\begin{array}{c}\text { Persentase } \\
(\%)\end{array}$ \\
\hline Benih ikan kerapu & 17 & 21,79 \\
Penyakit ikan & 15 & 19,23 \\
Pakan ikan & 14 & 17,95 \\
Biaya dan harga & 11 & 14,10 \\
Kualitas air & 5 & 6,41 \\
Sistem produksi pendederan & 7 & 8,97 \\
Kelangsungan hidup benih & 4 & 5,13 \\
Pertumbuhan benih & 2 & 2,56 \\
Keberlanjutan kegiatan & 2 & 2,56 \\
Regulasi & 1 & 1,28 \\
\hline Jumlah & 78 & 100,00 \\
\hline
\end{tabular}

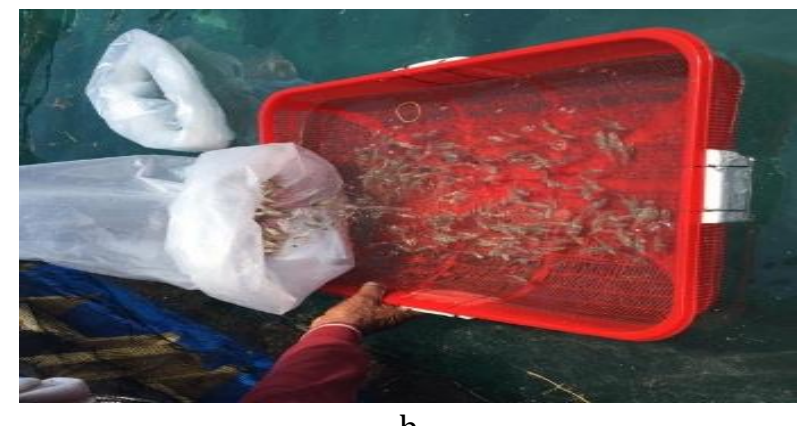

b

Gambar 4 a) Proses pengangkutan dan b) Penebaran benih ikan kerapu ke dalam keramba jaring apung percontohan. 
Wahyuningrum et al. 2016). Bawang putih dipotong tipis, kemudian dikeringkan dan dibuat tepung dengan menggunakan grinder. Kedua tepung tersebut ditambahkan ke pakan buatan masing-masing sebanyak 20 dan $25 \mathrm{~g} / \mathrm{kg}$ pakan dengan metode coating. Tepung bawang putihmeniran, putih telur, dan air dicampur dan diaduk dengan mixer hingga homogen. Campuran ini selanjutnya dicampur dengan pakan menggunakan mesin coating hingga merata, kemudian dikeringkan dalam oven pada $50^{\circ} \mathrm{C}$ selama 3-5 jam, lalu dikeringudarakan.

Pakan yang telah di-coating tepung meniran dan bawang putih diberikan kepada benih ikan kerapu cantang dalam sistem pendederan di KJA secara at satiation dengan pemberian 3 kali per hari, yaitu pukul 08.00, 12.00, dan 17.00 WIB. Ikan kerapu cantang berukuran $8 \mathrm{~cm}$ dipelihara dalam KJA berukuran $1 \times 1 \times 1,5$ m sebanyak 9 unit selama 28 hari. Pakan yang habis selama pemeliharaan dicatat dan dibandikan dengan biomasa ikan kerapu yang diperoleh guna menghitung rasio konversi pakan (feed converion ratio, FCR). Penelitian aksi ini dilakukan dengan rancangan acak lengkap (RAL) dengan tiga perlakuan dengan tiga ulangan. Perlakuan yang diberikan adalah pemberian tepung meniran dan bawang putih melalui pakan dengan lama waktu yang berbeda, yaitu 0, 7, dan 14 hari.

Berdasarkan penelitian Pratama \& Wahyuningrum (2020) mendapatkan tingkat kelangsungan hidup ikan kerapu cantang ini relatif tinggi pada semua perlakuan, yakni lebih dari 90\% (Tabel 4). Beberapa hasil penelitian menunjukkan kelangsungan hidup ikan kerapu pada stadia juvenil dalam fase pendederan kurang dari 80\% (Apines-Amar et al. 201; Muhammadar et al. 2014). Hasil penelitian aksi ini menunjukkan keberhasilan percontohan dan memberi motivasi kepada peserta untuk memulai usaha pendederan ikan kerapu. Dari diskusi yang berlangsung pada saat pelatihan dan kunjungan lapangan umumnya peserta kegiatan merasa tidak percaya diri untuk memelihara ikan kerapu yang berukuran $<11 \mathrm{~cm}$. Umumnya mereka merasa khawatir terjadi kematian yang tinggi pada ikan kerapu karena berukuran kecil dan kesulitan pemberian pakan. Percontohan usaha yang berhasil dapat mempermudah proses disemininasi teknologi dan manajemen produksi (Voeten \& Ottens 1997).

Pemberian tepung meniran-bawang putih ke benih ikan kerapu melalui pakan dengan lama pemberian yang berbeda ternyata bisa memperbaiki FCR (Pratama \& Wahyuningrum 2020). Ikan kerapu yang diberi bahan herbal tersebut, baik dengan lama pemberian tujuh hari maupun 14 hari, ternyata memiliki rasio konvseri pakan yang lebih baik dibandingkan dengan tanpa pemberian (kontrol), meskipun kelangsungan hidup dan pertumbunan adalah sama untuk semua perlakuan. Hal ini diduga disebabkan oleh meningkatnya nafsu makan ikan akibat pemberian bahan herbal tersebut (Wahyuningrum et al. 2013). Flavonoid dan polisakarida yang terkandung dalam tepung meniran dan bawang putih mampu merangsang nafsu makan (Pu et al. 2017). Bawang putih kaya akan polisakarida yang merupakan prebiotik yang dapat mendorong pertumbuhan mikrobiota saluran pencernaan yang bisa menekan pertumbuhan mikrobiota patogen, meningkatkan pemanfaatan pakan, dan memperbaiki kualitas daging ikan (Song et al. 2014; Gabriel et al. 2019). Bawang putih juga mengndung allisin yang berpengaruh positif terhadap mikroflora usus, sehingga bisa memperbaiki proses pencernaan (Moulia et al. 2018). Meniran mampu meningkatkan palatabilitas dan kecernaan sehingga menghasilkan pertumbuhan dan FCR yang lebih baik (Srivastava et al. 2019).

\section{Analisis Usaha}

Analisis usaha dilakukan pada pengembangan TTG aplikasi tepung meniran-bawang putih pada pendederan ikan kerapu cantang, dan pendederan ikan kerapu bebek yang diakukan oleh salah satu peserta kegiatan. Kedua kegiatan tersebut dilakukan secara paralel. Aplikasi tepung meniran dan bawang putih bisa memperbaiki FCR ikan kerapu. Perbaikan FCR ini tentu bisa menghemat penggunaan pakan dan

Tabel 4 Kinerja produksi ikan kerapu cantang Epinephelus sp. pada percontohan pendederan dalam keramba jaring apung di laut (Pratama \& Wahyuningrum 2020)

\begin{tabular}{lccc}
\hline \multirow{2}{*}{ Kinerja produksi } & \multicolumn{2}{c}{ Lama pemberian tepung meniran-bawang putih } \\
\cline { 2 - 4 } & Kontrol & 7 hari & 14 hari \\
\hline Kelangsungan hidup (\%) & $93,33 \pm 3,06^{\mathrm{a}}$ & $94,33 \pm 3,06^{\mathrm{a}}$ & $94,67 \pm 1,15^{\mathrm{a}}$ \\
Laju pertumbuhan spesifik (\%) & $3,27 \pm 0,14^{\mathrm{a}}$ & $3,38 \pm 0,14^{\mathrm{a}}$ & $3,79 \pm 0,43^{\mathrm{a}}$ \\
Rasio konversi pakan & $0,95 \pm 0,09^{\mathrm{b}}$ & $0,79 \pm 0,03^{\mathrm{a}}$ & $0,79 \pm 0,03^{\mathrm{a}}$ \\
\hline
\end{tabular}

${ }^{*}$ Huruf yang berbeda pada baris yang sama menunjukkan berbeda nyata $(\mathrm{P}<0,05)$ 
menurunkan biaya produksi (Tabel 5). FCR ikan yang diberi pakan yang diberi tepung meniran dan bawang putih sekitar 0,79 , sedangkan tanpa bahan herbal ini sekitar 0,95. Ini artinya untuk memproduksi benih ikan kerapu cantang sebanyak $1 \mathrm{~kg}$ diperlukan pakan dengan dan tanpa bahan herbal masing-masing sebanyak 790 dan $950 \mathrm{~kg}$. Biaya pakan per kg produk pendederan ini adalah $\mathrm{Rp} 23.700$ dan 28.500 masing-masing untuk pakan dengan dan tanpa penambahan tepung meniran dan bawang putih. Biaya total pakan yang diberi tepung meniran dan bawang putih ini masih lebih rendah dibandingkan dengan yang tanpa pemberian bahan herbal tersebut. Dari penelitian aksi tersebut maka dapat disimpulkan bahwa aplikasi tepung meniran dan bawang putih melalui pakan bisa menjadi TTG pada pendederan ikan kerapu dalam KJA di laut dengan lama pemberian tujuh hari.

Salah satu peserta telah mencoba melakukan usaha pendederan ikan kerapu secara mandiri. Ikan kerapu yang dipilih oleh peserta tersebut adalah ikan kerapu bebek yang memiliki harga dan prospek pasar yang lebih tinggi di- bandingkan dengan ikan kerapu lainnya. Ikan kerapu yang biasa dibudidayakan di Kepulauan Seribu, yaitu ikan kerapu macan, ikan kerapu cantang, atau ikan kerapu cantik. Ikan kerapu bebek ukuran 4-5 cm sebanyak 500 ekor ditebar dalam satu unit KJA ukuran 3 × 3 × 3 m dengan ketinggian air $2 \mathrm{~m}$. Ikan ini diberi pakan buatan berbentuk butiran (granule), selanjutnya diganti dengan pakan alami (ikan rucah) secara bertahap mulai minggu pertama hingga 2 minggu pemeliharaan. Selama 2 bulan pemeliharaan ukuran ikan kerapu bebek mencapai ukuran sekitar $9 \mathrm{~cm}$ dengan kelangsungan hidup sebesar $68 \%$. Ikan kerapu bebek ini dikenal memiliki pertumbuhan yang relatif lebih lambat dibandingkan dengan ikan kerapu lainnya (Williams et al. 2004). Meskipun kematian ikan dalam sistem pendederan salah seorang peserta ini relatif tinggi, namun hasil analisis usaha menunjukkan masih menguntungkan (Tabel 6). Alokasi waktu peserta dan pemanfaatan fasilitas produksi untuk usaha pendederan ini sebagai usaha barunya hanya $12,5 \%$, sisanya untuk mengelola usaha pembesaran ikan kerapu cantang yang sudah digeluti lebih awal.

Tabel 5 Perbandingan biaya pakan dengan dan tanpa pemberian tepung meniran-bawang putih pada pendederan ikan kerapu cantang Epinephelus sp. dalam keramba jaring apung di laut

\begin{tabular}{lcc}
\hline \multicolumn{1}{c}{ Uraian } & $\begin{array}{c}\text { Pakan dengan tepung meniran- } \\
\text { bawang putih }\end{array}$ & $\begin{array}{c}\text { Pakan tanpa tepung } \\
\text { meniran-bawang putih }\end{array}$ \\
\hline Feed Conversion Ratio & 0,79 & 0,95 \\
Kebutuhan Pakan per kg Biomasa Ikan (g) & 790 & 950 \\
Biaya Pakan per kg Biomasa Ikan (Rp) & 23.700 & 28.500 \\
Biaya Tepung Meniran-Bawang Putih (Rp) & 3.150 & 0 \\
\hline Biaya Pakan Total (Rp) & 26.850 & 28.500 \\
\hline
\end{tabular}

Tabel 6 Analisis usaha pendederan ikan kerapu bebek (Cromileptes altivelis) yang dilakukan oleh salah seorang peserta kegiatan selama 60 hari (2 bulan) pemeliharaan

\begin{tabular}{|c|c|c|c|c|c|}
\hline Komponen & Volume & Satuan & Harga (Rp) & Satuan & Jumlah (Rp) \\
\hline \multicolumn{6}{|l|}{ 1. Biaya } \\
\hline \multicolumn{6}{|l|}{ Biaya tetap } \\
\hline a. Penyusutan KJA & 2 & bulan & $69.444,4$ & Rp/bulan & $138.888,9$ \\
\hline b. Penyusutan kapal & 2 & bulan & $200.000,0$ & Rp/bulan & $400.000,0$ \\
\hline c. Penyusutan peralatan & 2 & bulan & $13.888,9$ & & $27.777,8$ \\
\hline Sub-jumlah & & & & & $538.888,9$ \\
\hline Biaya variable & & & & & - \\
\hline a. Benih & 500 & ekor & $12.500,0$ & Rp/ekor & $6.250 .000,0$ \\
\hline b. Pakan & 60 & $\mathrm{~kg}$ & $5.000,0$ & $\mathrm{Rp} / \mathrm{kg}$ & $300.000,0$ \\
\hline c. BBM & 45 & $\mathrm{~L}$ & $8.000,0$ & $\mathrm{Rp} / \mathrm{L}$ & $360.000,0$ \\
\hline d. Tenaga kerja & 0,25 & Bulan*) & $4.276 .349,0$ & Rp/bulan & $1.069 .087,3$ \\
\hline Sub-jumlah & & & & & 7.979.087,3 \\
\hline Jumlah Biaya & & & & & $8.517 .976,1$ \\
\hline 2. Penerimaan & 340 & ekor & $27.500,0$ & Rp/ekor & $9.350 .000,0$ \\
\hline 3. Keuntungan & & & & & $832.023,9$ \\
\hline
\end{tabular}

*) Alokasi waktu peserta dalam mengelola usaha poendederan sebanyak $12,5 \%$. 
Kematian ikan kerapu bebek yang mencapai $32 \%$ yang terjadi pada usaha pendederan ikan kerapu bebek yang berlangsung antara OktoberNovember tersebut diduga disebabkan oleh kondisi oseanografi. Kegiatan berlangsung pada saat musim pancaroba, yakni peralihan dari Musim Timur ke Musim Barat. Menurut Sachoemar (2008) kondisi angin di Kepulauan Seribu sangat dipengaruhi angin monsoon, yaitu Angin Musim Barat (Desember-Maret) dan Angin Musim Timur (Juni-September). Musim Pancaroba terjadi antara bulan April-Mei dan Oktober-November. Kecepatan angin pada musim Barat bervariasi antara 7-20 knot/jam dan bertiup dari barat daya sampai barat laut. Angin kencang dengan kecepatan 20 knot/jam biasanya terjadi antara bulan DesemberFebruari. Pada musim Timur kecepatan angin berkisar 7-15 knot/jam yang bertiup dari arah Timur sampai Tenggara. Tingginya kecepatan angin ini berdampak kepada dinamika air laut, terutama ketinggian (amplitudo) gelombang dan kecepatan arus air. Pada saat pendederan berlangsung gelombang dan kecepatan arus air laut relatif tinggi yang bisa menyebabkan stres pada ikan kerapu bebek yang berukuran relatif kecil, dan menyebabkan penurunan nafsu makan. Menurut Effendi et al. (2016) pada Musim Barat kandungan bahan organik total (total organic matter, TOM) di perairan Pulau Semak Daun menjadi relatif tinggi dibandingkan dengan Musim Barat, yang diduga disebabkan oleh tingginya dinamika air laut.

Ikan kerapu bebek tersebut diduga terserang penyakit mulut merah yang disebabkan oleh bakteri vibrio (Hadiroseyani et al. 2010; Sarjito et al. 2012). Penyakit ini ditandai oleh mulut yang berwarna merah karena pendarahan dan sirip yang sobek-sobek dan akhirnya buntung. Penyakit ini biasanya memiliki frekuensi kejadian yang tinggi pada perairan dengan kandungan TOM yang tinggi. Tingginya TOM disebabkan oleh musim yang berlaku pada saat kegiatan pendederan berlangsung seperti telah diurai di atas. Tingginya kandungan TOM dan stres pada ikan kerapu bebek menjadi penyebab tingginya tingkat serangan penyakit yang disebabkan oleh bakteri vibrio, yang pada gilirannya menyebabkan kematian. Untuk mengantisipasi kondisi tersebut maka perlu upaya untuk meningkatkan daya tahan tubuh ikan kerapu antara lain dengan menerapkan TTG aplikasi bahan herbal melalui pakan dan memperhatikan kualitas pakan yang diberikan. Untuk pertumbuhan yang optimal dan retensi nutrien, ikan kerapu bebek memerlukan pakan dengan kandungan protein yang tinggi dan lipid yang moderat (William et al. 2004). Sementara itu, berdasarkan hasil wawancara dengan pelaku pendederan percontohan ini diperoleh informasi bahwa pada saat gelombang dan arus laut relatif tinggi nelayan tidak melaut, sehingga pasokan ikan rucah untuk ikan kerapu budi daya tersendat. Tampaknya perlu pendampingan lanjutan kepada pelaku pendederan pemula ini untuk bisa mengatasi permasalahan penyakit dan pakan pada benih ikan kerapu, dan memperhatikan musim yang sesuai untuk masa pendederan.

Kegiatan ini diharapkan bisa meningkatkan kapasitas SDM dan mengembangkan TTG, sehingga bisa meningkatkan kinerja produksi ikan kerapu, baik pendederan khususnya maupun pembesaran pada umumnya. Perbaikan kinerja ini, bersama-sama dengan peningkatkan efisiensi produksi, diharapkan bisa meningkat komersialisasi dan investasi yang pada gilirannya bisa meng-upgrade rantai pasok pada agribisnis ikan kerapu seperti yang diperoleh oleh Kaminski et. al. (2017).

\section{SIMPULAN}

Kegiatan pengembangan pendederan ikan kerapu mencakup pengembangan SDM (pelatihan, percontohan, dan pendampingan) dan TTG (penelitian aksi aplikasi tepung meniran dan bawang putih). Dari kegiatan tersebut terjadi peningkatan pengetahuan peserta dalam mendederkan ikan kerapu di KJA laut. Dari kegiatan ini juga dihasilkan TTG dalam pendederan ikan kerapu cantang berupa aplikasi tepung meniran dan bawang putih dengan lama pemberian tujuh hari. TTG ini memberikan nilai FCR lebih baik, sehingga bisa menghemat biaya pakan. Salah seorang peserta kegiatan telah melakukan usaha pendederan ikan kerapu bebek dalam KJA di laut secara menguntungkan. Perlu upaya lanjutan untuk mengembangkan usaha pendederan ikan kerapu dalam KJA di laut, antara lain: membuka akses permodalan untuk peserta, memberikan pendampingan lanjutan, menerapkan TTG aplikasi tepung meniran dan bawang putih melalui pakan, dan memperhatikan musim saat memulai usaha. 


\section{UCAPAN TERIMA KASIH}

Penulis mengucapkan terima kasih kepada Direktorat Riset dan Pengabdian Masyarakat, Deputi Bidang Penguatan Riset dan Pengembangan, Kementerian Riset dan Teknologi/Badan Riset dan Inovasi Nasional sesuai dengan Kontrak Pelaksanaan Program Pengabdian Masyarakat Nomor: 001/SP2H/PPM/DRPM/ 2020 tanggal 16 Maret 2020. Terima kasih juga disampaikan kepada Lembaga Penelitian dan Pengabdian pada Masyarakat IPB yang telah memberi penugasan dan fasilitasi dalam kegiatan ini. Terima kasih tentunya juga disampaikan kepada Lurah Kelurahan Pulau Panggang, Ketua Pokdakan Sea Farming, UPBL, dan NKPS yang membantu pelaksanaan kegiatan ini sejak pelatihan, percontohan, dan pendampingan.

\section{DAFTAR PUSTAKA}

Akbar S, Marsoedi, Soemarno, Kusnendar E. 2012. Pengaruh pemberian pakan yang berbeda terhadap pertumbuhan ikan kerapu macan (Ephinephelus fuscoguttatus) pada fase pendederan dikeramba jaringapung. Teknologi Pangan: Media Informasi dan Komunikasi Ilmiah Teknologi Pertanian. 4(1): 93-101. tp.v4i1.492

Apines-Amar MJS, Amar EC, Faisan Jr. JP, Pakingking Jr. RV, Satoh S. 2012. Dietary onion and ginger enhance growth, hematoimmunological responses, and disease resistance in brown-marbled grouper, Epinephelus fuscoguttatus. AACL Bioflux. 5(4): 231-239.

[BPS] Badan Pusat Statistik. 2020. Kabupaten Kepulauan Seribu dalam Angka 2020. Jakarta [ID]: Badan Pusat Statistik, Kabupaten Kepulauan Seribu.

Davis-Hodgkins M. 1999. Aquaculture training and education: An applied approach for industry. World Aquaculture Magazine. 30(3): 31-34.

Dickson M, Nasr-Allah A, Kenawy D, Kruijssen F. 2016. Increasing fish farm profitability through aquaculture best management practice training in Egypt. Aquaculture. 465(2016): 172-178. https://doi.org/10. 1016/j.aquaculture.2016.09.015
Effendi I. 2010. Pengantar Akuakultur. Jakarta (ID): PT Penebar Swadaya.

Effendi I. 2019. Bangkitkan Pendederan Kerapu di Kepulauan Seribu. Trobos Aqua. [Internet]. [Diakses pada: Januari 2021]. Tersedia pada: http://trobosaqua.com/detailberita/2019/12/15/14/12470/irzal-effendibangkitkan-pendederan-kerapu-dikepulauan-seribu.

Effendi I, Suprayudi MA, Nurjaya IW, Surawidjaja EH, Supriyono E, Junior MZ, Sukenda. 2016. Oceanography and water quality condition in several waters of thousand islands and its suitability for white shrimp Litopenaeus vannamei culture. Jurnal Ilmu dan Teknologi Kelautan Tropis. 8(1): 403-417. https:// doi.org/10.29244/jitkt.v8i1.13912

Gabriel NN, Wilhelm MR, Habte-Tsion HM, Chimwamurombe P, Omoregie E. 2019. Dietary garlic (Allium sativum) crude polysaccharides supplementation on growth, haematological parameters, whole body composition and survival at low water $\mathrm{pH}$ challenge in African catfish (Clarias gariepinus) juveniles. Scientific African 5(2019): 1-11. https://doi.org/10.1016/ j.sciaf.2019.e00128

Hadiroseyani Y, Effendi I, Rahayu AM, Arianty HS. 2010. Infestasi parasit pada benih ikan kerapu macan (Epinephelus fuscoguttatus) di Karamba Jaring Apung Balai Sea Farming, Kepulauan Seribu Jakarta. Jurnal Akuakultur Indonesia 9(2): 140-145. https://doi.org/ 10.19027/jai.9.140-145

Ikhsani FW. 2011. Profil Kelopok Sea Farming Pulau Panggang dalam Optimasi Pengelolaan dan Pengembangan Budi Daya Ikan Kerapu Macan pada Kelompok Sea Farming Di Pulau Panggang Kabupaten Administratif Kepulauan Seribu. [Skripsi]. Bogor (ID): Institut Pertanian Bogor.

Ismi S. 2010. Pendederan kerapu bebek (Cromileptes altivelis) sebagai salah satu usaha untuk meningkatkan pendapatan petani pada pembenihan ikan laut. Dalam: Prosiding Simposium Nasional Pembangunan Sektor Kelautan dan Perikanan Kawasan Timur Indonesia. Balitbang Kelautan dan Perikanan, Jakarta (ID), 2010.

[ITECH] International Training and Education Center for Health. 2010. Guidelines for Pre- 
and Post-testing. I-TECH Technical Implement Guide. Seatle, Washington [USA]: University of Washington.

Kaminski AM, Genschick S, Kefi AS, Kruijssen F. 2017. Commercialization and upgrading in the aquaculture value chain in Zambia. Aquaculture. 493: 355-364. https://doi.org/ 10.1016/j.aquaculture.2017.12.010

Love DC, Allison EH, Asche F, Belton B, Cottrell RS, Froehlich HE10, Gephart JA, Hicks CC, Little DC, Nussbaumer EM, Pinto da Silva P, Poulain F, Rubio A, Stoll JS, Tlusty MF, Thorne-Lyman AL, Troell M, Zhang W. 2021. Emerging COVID19 Impacts, Responses, and Lessons for Building Resilience in the Seafood System. Global Food Security. 28(2021): 1-11. https://doi.org/10.1016/j.gfs.2021.100494

Moulia MN, Syarief R, Iriani ES, Kusumaningrum HD, Suyatma NE. 2018. Antimicrobial of garlic extract. Jurnal Pangan. 27(1): 55-66.

Muhammadar AA, Mazlan AG, Samat A, Asmawati MS, Muchlisin ZA, Rimmer MA, Simon KD. 2014. Growth, survival and feed conversion of juvenile tiger grouper Epinephelus fuscoguttatus in different salinity regimes. AACL Bioflux. 7(4): 241-247.

Obiero KO, Waidbacher H, Nyawanda BO, Munguti JM, Manyala JO, Kaunda-Arara B. 2019. Predicting uptake of aquaculture technologies among smallholder fish farmers in Kenya. Aquaculture International. (27):1689-1707. https://doi.org/10. 1007/s10499-019-00423-0

Pratama AT, Wahyuningrum D. 2020. Penggunaan tepung meniran-bawang putih dalam pakan pada pendederan ikan kerapu dalam keramba jaring apung di laut. [Skripsi]. Bogor (ID): Institut Pertanian Bogor.

Pu H, Li X, Du Q, Cui H, Xu Y. 2017. Research progress in the application of Chinese herbal medicines in aquaculture: $A$ Review. Engineering. 3(5): 731-737. https://doi.org/ 10.1016/J.ENG.2017.03.017

Rouhani Q, Britz PJ. 2011. Participatory development of provincial aquaculture programmes for improved rural food security and livelihood alternatives. In Report to the Water Research Commission and Department of Agriculture, Forestry and Fisheries. Rural Fisheries Programme Department of
Ichthyology and Fisheries Science Rhodes University. South Africa (ZA). 113pp.

Sachoemar SI. 2008. Karakteristik lingkungan perairan Kepulauan Seribu. Jurnal Air Indonesia 4(2):109-114. https://doi.org/10. 29122/jai.v4i2.2408

Sari YD, Kusumastanto T, Adrianto L. 2008. Maximum economic yield sumberdaya perikanan kerapu di perairan Kepulauan Seribu, DKI Jakarta. Jurnal Sosial Ekonomi Kelautan dan Perikanan. 3(1):69-78. https:// doi.org/10.15578/jsekp.v3i1.5843

Sari YD, Nababan BO. 2009. Tingkat optimal pengelolaan sumber daya ikan kerapu di perairan Kepulauan Seribu, DKI Jakarta. Globe Majalah Ilmiah. 11(1): 31-42.

Sarjito S, Radjasa O, Hutabarat S, Prayitno S. 2012. Causitive agent vibriosis dari ikan kerapu bebek (Cromileptis altivelis) bermulut merah: 1. Patogenitas pada ikan kerapu macan (Epinephelus fuscoguttatus). Indonesian Journal of Marine Sciences. 12(3): 173-180.

Soebagio. 2005. Analisis Kebijakan Pemanfaatan Ruang Pesisir dan Laut Kepulauan Seribu dalam Meningkatkan Pendapatan Masyarakat melalui Kegiatan Budidaya Perikanan dan Pariwisata. [Disertasi]. Bogor [ID]: Institut Pertanian Bogor.

Song SK, Beck BR, Kim D, Park J, Kim J, Kim HD, Ring $\varnothing \quad$ E. 2014. Prebiotics as immunostimulants in aquaculture: A review. Fish Shellfish Immunology. 40(1): 40-48. https://doi.org/10.1016/j.fsi.2014.06.016

Srinath K, Sridhar M, Kartha PNR, Mohanan AN. 2000. Group farming for sustainable aquaculture. Ocean \& Coastal Management. 43(7): 557-571. https://doi.org/ 10.1016/S0964-5691(00)00046-6

Srivastava A, Ansal MD, Khairnar SO. 2019. Effect of amla (Phyllanthus emblica) fruit powder supplemented feed on growth performance and proximate composition of an Indian major carp, Labeo rohita (Ham.) fingerlings. Journal of Entomology and Zoology Studies. 7(3): 955959.

Suhana. 2020. Dampak Covid-19 terhadap ekpsor kerapu hidup Indonesia. [Internent]. [Diakses pada:]. Tersedia pada: https://suhana.web.id/2020/03/20/dampak 
-covid-19-terhadap-ekspor-kerapu-hidupindonesia.

Trana N, Rodriguez UP, Chana CY, Phillipsa MJ, Mohana CV, Henrikssona PJG, Koeshendrajana S, Suria S, Hall S. 2017. Indonesian aquaculture futures: An analysis of fish supply and demand in Indonesia to 2030 and role of aquaculture using the AsiaFish model. Marine Policy. 79: $25-32$. marpol.2017.02.002

Voeten J, Ottens B. 1997. Gender training in aquaculture in Northern Vietnam: a report. Gender, Technology and Development. 1(3): 413-432. https://doi.org/10.1080/ 09718524.1997.11909870

Wahyuningrum D, Astrini A, Setiawati M. 2013. Pencegahan Aeromonas hydrophila pada benih ikan lele menggunakan bawang putih dan meniran. Jurnal Akuakultur Indonesia. 12(1): 86-94. https://doi.org/10.19027/jai.12.8694

Wahyuningrum D, Miranti S, Effendi I. 2016. Preventive and curative effects of Phyllanthus niruri-Allium sativum combination on tiger grouper Epinephelus fuscoguttatus infected by Vibrio alginolyticus. International Journal of Sciences: Basic and Applied Research (IJSBAR). 28(3): 154-167.

Williams KC, Irvin S, Barclay M. 2004. Polka dot grouper Cromileptes altivelis fingerlings require high protein and moderate lipid diets for optimal growth and nutrient retention. Aquaculture Nutrition. 10(2): 125-134. https://doi.org/10.1046/j.1365-2095.2003. 00285.x 